\title{
A geometric morphometric study of sex differences in the scapula, humerus and ulna of Chaetophractus villosus (Xenarthra, Dasypodidae)
}

\author{
Francisco Acuña', Nora S. Sidorkewicj'1,3, Albertina I. Popp' \& Emma B. Casanave2,3
}

\footnotetext{
1. Cátedra de Anatomía Comparada, Departamento de Biología, Bioquímica y Farmacia, Universidad Nacional del Sur, San Juan 670, 8000, Bahía Blanca, Argentina. (francisco.acuna@uns.edu.ar; nsidorke@criba.edu.ar; albertinapopp@hotmail.com)

2. Cátedra de Fisiología Animal, Departamento de Biología, Bioquímica y Farmacia, Universidad Nacional del Sur, San Juan 670, 8000, Bahía Blanca, Argentina

(casanave@criba.edu.ar)

3. INBIOSUR (CONICET-UNS)
}

Received 26 May 2016

Accepted 22 November 2016

DOI: $10.1590 / 1678-4766 e 2017010$

\begin{abstract}
Sexual differences in some of the components of the pectoral girdle and forelimb of Chaetophractus villosus (Desmarest, 1804) were investigated by means of geometric morphometrics. A total of 15 scapulae ( 7 males, 8 females) and 50 humeri-ulnae complexes ( 24 males, 26 females) were examined. No size differences were detected between sexes for any of the bones, but shape differences were found for the humerus and the ulna that enhance the in-forces or the related in-levers. Females had a more robust humerus, with an enlarged deltoid tuberosity, a more spherical head, higher tubercular and epicondylar widths, and more developed supracondylar crests. The ulna of the females was characterised by a more pronounced curvature along its main axis, a caudal displacement of the lateral fossa, a longer olecranon, and a deeper trochlear notch. For both bones, the discriminant analysis classified correctly all the specimens according to their sex. A small percentage of the variance (5.2\% for the humerus; $6.8 \%$ for the ulna) was explained by allometry. The morphological traits found for the humerus and ulna of the females suggest an increased structural strength that could result in powerful digging strokes while keeping shoulder and elbow stabilisation, suggesting a fossorial advantage over males.
\end{abstract}

KEYWORDS. Large hairy armadillo, fossorial mammals, shape-based dimorphism, appendicular skeleton.

RESUMEN. Estudio del dimorfismo sexual en la escápula, húmero y ulna de Chaetophractus villosus (Xenarthra, Dasypodidae) mediante técnicas de morfometría geométrica. Se investigaron las diferencias sexuales en algunos de los elementos de la cintura escapular y del miembro anterior de Chaetophractus villosus (Desmarest, 1804) utilizando técnicas de morfometría geométrica. La muestra estuvo constituida por 15 escápulas (7 machos, 8 hembras) y 50 complejos húmero-ulna ( 24 machos, 26 hembras). No se detectaron diferencias de tamaño entre sexos para ninguno de los tres huesos. Sin embargo, se observaron diferencias de forma para el húmero y la ulna, con mayor desarrollo en las hembras de estructuras que favorecen el incremento de fuerzas internas o de las palancas internas relacionadas. En ellas, el húmero se caracterizó por una morfología general más robusta, con mayor desarrollo de la tuberosidad deltoidea, cabeza más esférica, mayores anchos intertubercular y epicondilar, y mayor desarrollo de las crestas supracondilares. Para la ulna se observó una curvatura más pronunciada a lo largo de su eje mayor, desplazamiento de la fosa lateral hacia caudal, olecranon de mayor desarrollo, e incisura troclear más profunda. Para ambos huesos, el análisis discriminante clasificó correctamente al total de los ejemplares de acuerdo al sexo. Un pequeño porcentaje de la varianza (5,2\% para el húmero; $6,8 \%$ para la ulna) se debió a efectos alométricos. Las características morfológicas del húmero y la ulna de las hembras sugieren una ventaja fosorial sobre los machos, debido a una mayor fuerza estructural durante los movimientos involucrados en el cavado, al tiempo que se mantiene una gran estabilidad en las articulaciones del hombro y del codo.

PALABRAS-CLAVE. Peludo, mamíferos fosoriales, diferencias de forma, esqueleto apendicular.

The dasypodids or armadillos, represent the most diverse group of living xenarthrans and one of the most bizarre group of mammals. Native from South America, they constitute a significant part of the fauna of the continent (GARDNER, 2005). Twenty one extant species are recognised, grouped into five tribes (Euphractini, Dasypodini, Tolypeutini, Priodontini, Chlamyphorini), the majority of which are present in Argentina (REDFORD \& EISENBERG, 1992; GARDNER, 2005; WeTZEL et al., 2008).

Most species of armadillos develop fossorial habits, digging burrows which serve temporarily as places of protection from adverse weather conditions, nest and shelter from predators (McDonOugh \& LOUGHRY, 2008). Framed as the most powerful scratch-diggers (HILDEBRAND, 1985), they are characterised by the possession of strong and clawed forelimbs that generate forces at the expense of stride length and speed of limb movement (MAYNARD SMITH \& SAVAGE, 1956; Hildebrand, 1985). Although certain degree of variation can occur among species, common characteristics are short and massive bones provided with large areas for the insertion of well-developed muscles and long leverarms that allow increasing the mechanical advantage for the main muscular action (HILDEBRAND, 1985; VIZCAÍNO \& Milne, 2002; Kley \& Kearney, 2007; Polly, 2007; 
MiLne et al., 2009). Thus, the humerus bears a stout and long deltoid tuberosity (insertion of the m. deltoideus, important in shoulder stabilization and flexion of the arm), and an enlarged medial epicondyle (origin of the pronator teres, for forearm pronation, and of some of the digital and carpal flexors). In the ulna, meanwhile, the olecranon reaches a length which can be about $2 / 3$ the ulnar length distal to the pivot at the elbow joint (HILDEBRAND, 1985), constituting thus a markedly increased area of insertion for the main elbow extensors, such as the triceps and the anconeus. Adaptive modifications can affect also the pectoral girdle, and they are most evident in the shape of the scapula, characterised by an enlargement of its posteromedial angle (increased area of origin for the teres major, one of the main retractors of the forelimb) and a highly developed acromion process (increased area of origin for the acromial portion of the deltoideus) (Galton, 1868; Windle \& Parsons, 1899; Burne, 1901; Miles, 1941; Hildebrand, 1985; VizCAÍNo et al., 1999; KLEy \& Kearney, 2007).

Several authors have dedicated efforts to study the adaptations of the appendicular skeleton of different species of dasypodids. Some of them have examined the components of the forelimb from a strictly morphological or even morphofunctional point of view (MiLes, 1941; MonTEIRO \& ABE, 1999; Monteiro, 2000; Milne et al., 2009; Galliari, 2014). Others have focused in their burrowing ability based mainly on indices obtained as proportions between proximal and middle bones of the forelimb (VIZCAÍNO et al., 1999; VizCAíno \& MiLNE, 2002), which in general have demonstrated a good correlation with digging habits. Taking into account one of such indices (index of fossorial ability, IFA), VizCAíno et al. (1999) divided the armadillos into three categories according their fossorial habits, which were slightly modified by Mirne et al. (2009) and VizCAíno et al. (2012) as follows: (1) species that are mainly ambulatory ("non-diggers", e.g. Tolypeutes matacus); (2) species that dig short burrows for protection or to seek food, and that feed on the surface or just below it ("generalised diggers", represented by members of the tribes Euphractini and Dasypodini); (3) species that are either burrowers or those that feed on termites or ants ("specialised diggers", exemplified by members of the tribes Priodontini and Chlamyphorini).

Chaetophractus villosus (Desmarest, 1804), an Euphractini commonly known as large hairy armadillo, is the biggest species of the genus. It can be considered a generalised digger according the classification of VIZCAÍNO et al. (1999). Although there exist several studies that aim to elucidate the adaptations of the appendicular skeleton of this species in relation to its lifestyle (VIZCAíno et al., 1999, 2003; VizCaíno \& Milne, 2002; Milne et al., 2009; Galliari, 2014), knowledge about it is still incomplete. If taking into account the characteristics of such elements in males and females, which may serve as a basis for determining the fossorial ability of both sexes, information is null. The aim of the present study was to perform a geometric morphometric study of the scapula, humerus and ulna in males and females of $C$. villosus, in order to examine the existence of possible morphological differences in three of the main bones undergoing stress during burrowing.

\section{MATERIALS AND METHODS}

A total of 15 left scapulae ( 7 males, 8 females) and 50 humeri-ulna complexes of the left forelimb (24 males, 26 females) of adults of $C$. villosus were examined. The material are deposited in the dasypodid's collection of the Laboratorio de Anatomía Comparada, Departamento de Biología, Bioquímica y Farmacia, Universidad Nacional del Sur (UNS), Bahía Blanca, Argentina. Nomenclature of the specimens are composed by the species name (CVI: Chaetophractus villosus), sex (MA: male; HA: female), number of the specimen and date of collection (day.month. year).

Material examined. Collected in Buenos Aires province, ARGENTINA, between $37^{\circ} 41^{\prime}-38^{\circ} 46^{\prime} \mathrm{S}$ and $61^{\circ} 21^{\prime}$ ' - 624'W. Scapula: $7{ }^{\wedge}$ (CVIMA85, 01.V.1998; CVIMA88, 21.VII.2013; CVIMA90, 01.V.1998; CVIMA91, 04.IX.2013; CVIMA93, 20.IX.2013; CVIMA95, 27.XI.2014; CVIMA96, 27.XI.2014); 8 (CVIHA70, 18.VII.1997; CVIHA83, 04.IX.2013; CVIHA84, 04.IX.2013; CVIHA85, 04.IX.2013; CVIHA86, 20.IX.2013; CVIHA87, 20.IX.2013; CVIHA89, 21.VIII.2013; CVIHA 90, 27.XI.2014). Humerus and ulna: 24ð (CVIMA50, 19.VI.1995; CVIMA52, 16.VIII.1995; CVIMA57, 18.X.1996; CVIMA61, 04.IV.1997; CVIMA70, 14.VII.1997; CVIMA71, 18.VII.1997; CVIMA74, 25.IV.1998; CVIMA76, 24.IV.1998; CVIMA77, 01.V.1998; CVIMA78, 01.V.1998; CVIMA79, 01.V.1998; CVIMA80, 01.V.1998; CVIMA81, 01.V.1998; CVIMA83, 01.V.1998; CVIMA84, 01.V.1998; CVIMA85, 01.V.1998; CVIMA87, 14.VII.1998; CVIMA88, 21.VII.2013; CVIMA90, 01.V.1998; CVIMA91, 04.IX.2013; CVIMA92, 04.IX.2013; CVIMA93, 20.IX.2013; CVIMA95, 27.XI.2014; CVIMA96, 27.XI.2014); 26 우 (CVIHA41, 26.X.1994; CVIHA44, 02.XI.1994; CVIHA45, 21.XI.1994; CVIHA46, 08.XII.1994; CVIHA48, 01.IV.1995; CVIHA49, 12.VI.1995; CVIHA51, 13.VII.1995; CVIHA53, 16.VIII.1995; CVIHA54, 16.VIII.1995; CVIHA55, 01.VIII.1996; CVIHA56, 17.VIII.1996; CVIHA58, 31.X.1996; CVIHA59, 12.III.1997; CVIHA60, 04.IV.1997; CVIHA66, 30.V.1997; CVIHA69, 18.VII.1997; CVIHA70, 18.VII.1997; CVIHA73, 24.IV.1998; CVIHA75, 25.V.1998; CVIHA82, 01.V.1998; CVIHA83, 04.IX.2013; CVIHA84, 04.IX.2013; CVIHA85, 04.IX.2013; CVIHA86, 20.IX.2013; CVIHA87, 20.IX.2013; CVIHA89, 21.VIII.2013).

Data collection and analysis. Digital images were obtained from each bone (scapula in dorsal view; humerus in caudal view; ulna in lateral view). Several considerations were taking into account to avoid problems of parallax: $i$ - the camera was fixed at a constant visual distance with the aid of a vertical stand; ii- the material was successively placed in the middle of the visual campus, coordinated on a graph paper between horizontal and vertical lines; iii- all images were captured in one session. A serie of landmarks (scapula: 
7; humerus: 24; ulna: 19) were digitised using TPSDig2 software (RoHLF, 2010a), as indicated in Fig. 1.

For each bone, MorphoJ (version 1.05; KLINGENBERG, 2011) was used to perform Procrustes analysis in order to eliminate differences in position, orientation and scale so that only shape variation remained. Canonical analysis was applied to obtain the optimal separation plane between sexes, and the morphological variation was analysed by means of principal component and discriminant analysis. Also the Mahalanobis distance was calculated. Finally, regression of Procrustes coordinates vs the logarithm of the centroid size was performed to evaluate possible allometric effects.

Additionally, TPSRelw software (RoHLF, 2010b) was used to calculate the relative warps $(\alpha=0)$ as the principal component analysis (PCA) of Procrustes shape coordinates. The consensus configuration and the deformation grids of the first two relative warps were drawn in order to study the most important variations in shape between sexes.

An ANOVA (INFoSTAT, version 1.1, 2006) was performed over the logarithm of the centroid size of males and females to evaluate possible differences in size between sexes $(\mathrm{p} \leq 0.05)$.

\section{RESULTS}

Scapula. No differences in size were detected in the scapula of males and females $(\mathrm{p}=0.94)$. Shape variation between sexes was neither found (Mahalanobis: $p=0.11$; Procrustes: $\mathrm{p}=0.53$ ), which was probably due to the high individual variability of the bone, evident to the naked eye, combined with the low number of landmarks used and the low sample size available for the study.

Humerus. No differences in size were detected between sexes $(\mathrm{p}=0.36)$. However, shape differences were observed with the canonical analysis, with a highly significant Mahalanobis distance $(\mathrm{p}<0.0001)$, and a low $\mathrm{p}$-value in Procrustes analysis $(p=0.0013)$. Females characterised by a more generalised robustness of the bone than males, and the differences were seen mainly at the tubercular and epicondylar widths, at the deltoid tuberosity, and at the medial supracondylar crest (Fig. 2). The head of the bone was somewhat elongated and thin in males and more rounded in females. The discriminant analysis classified correctly all the specimens according to their sex.

In the PCA, although a clear separation between males and females was not evident in the plane of the first two PCs, the trends observed were the same as in the canonical analysis; these components accounted for $29.6 \%$ of the total variance. Along the main axis of variation ( $\mathrm{PC} 1$; $16.8 \%$ of the variance), low scores were associated with increased attachment sites for origin and insertion of muscles (enlargement of the lesser tubercle and medial epicondyle, strengthening of the deltoid tuberosity, higher development of both supracondylar crests), and with a higher roundness of the humeral head. Variation along PC2 (12.8\% of the total variance) was more noticeable in the deltoid tuberosity and in the entepicondyle (=medial epicondyle) development (Fig. 3).

The relative warp analysis showed a trend to segregation along RW1, with females predominantly associated to low scores and males to high scores. The greatest variation was found at landmarks 6 and 7 (deltoid tuberosity), which represented 25.5 and $22.4 \%$ of the
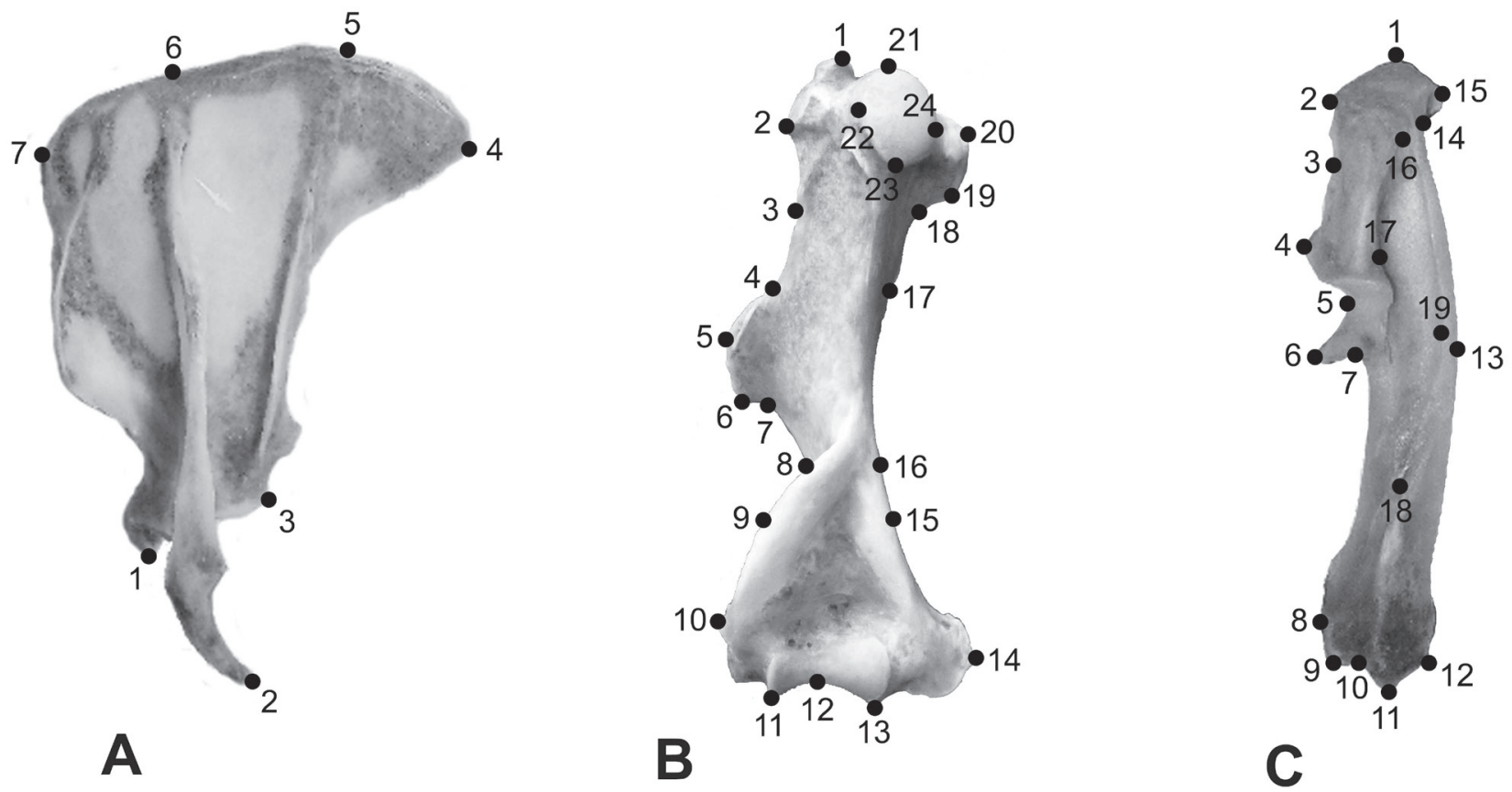

Fig. 1. Landmarks digitised on the left appendicular bones of Chaetophractus villosus (Desmarest, 1804). Scapula in dorsal view; humerus in caudal view; ulna in lateral view. 

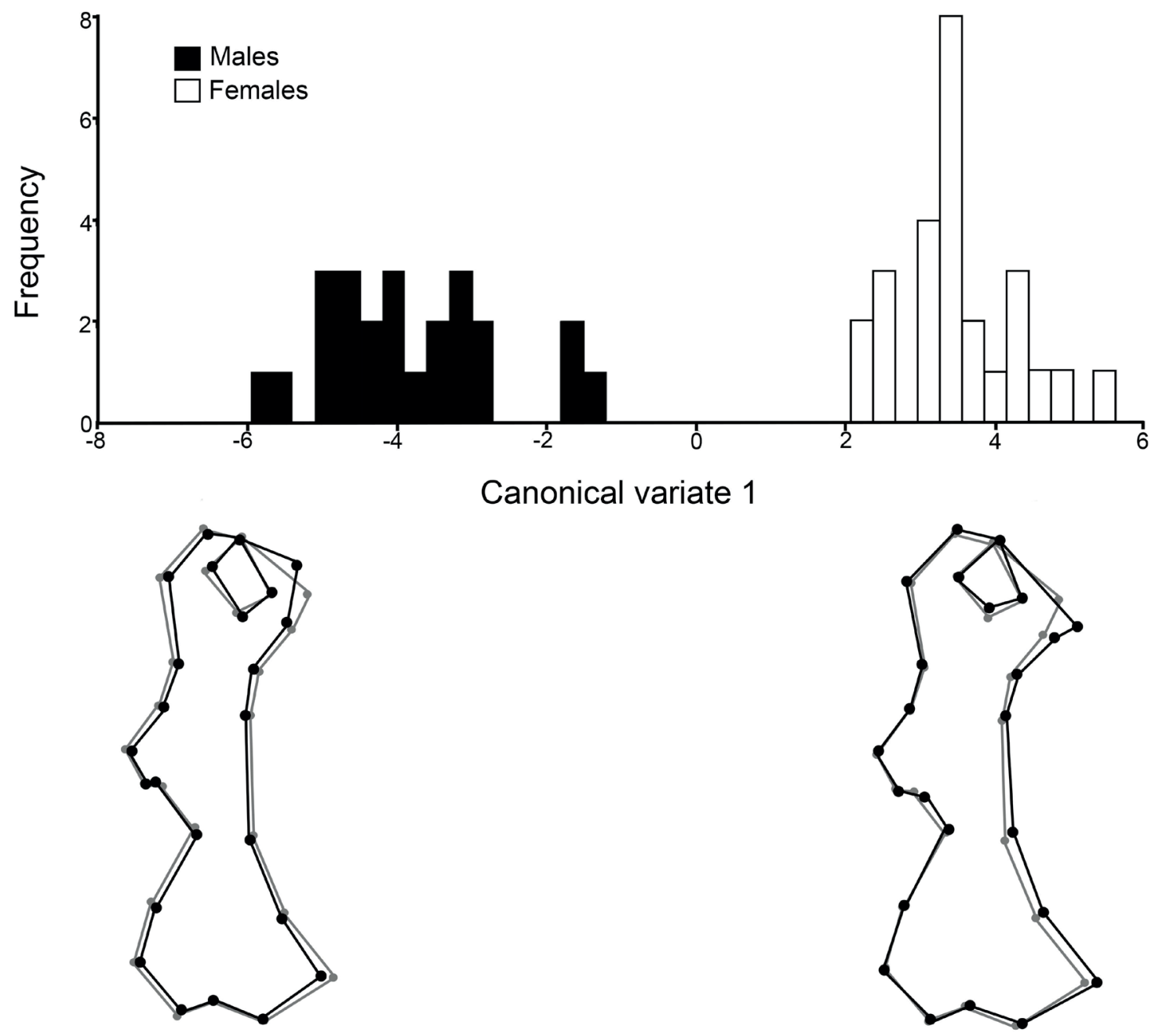

Fig. 2. Canonical analysis for the humerus of males and females of Chaetophractus villosus (Desmarest, 1804). The bone outlines below the graph represent the tendencies to deformation in males and females (black dots and lines) with respect to the consensus of the species (grey dots and lines) along the axis.

variance, respectively (Fig. 4).

Since no differences in size were detected between sexes, the regression between Procrustes coordinates and the logarithm of the centroid size was performed using the whole data set; this analysis demonstrated that only $5.2 \%$ of the variance was explained by allometry $(\mathrm{p}=0.0008)$.

Ulna. No sexual dimorfism related to size was detected $(\mathrm{p}=0.20)$. The canonical analysis found shape differences between sexes, with significant Mahalanobis distance $(\mathrm{p}<0.0001)$ and a significant $\mathrm{p}$-value for Procrustes distances from permutation tests $(\mathrm{p}=0.03)$. Females had a more curved bone along its major axis, a caudal displacement of the lateral fossa and a longer olecranon (Fig. 5). The discriminant analysis correctly classified the $100 \%$ of the specimens.

In the PCA, the first two PCs explained a higher percentage of the total variance $(47.5 \%)$ than in the case of the humerus. PC1 accounted for $25.2 \%$ of the total variability; high scores were associated mainly with a higher ulnar curvature and a more distally displaced lateral fossa. Shape variability along PC2 (22.3\%) showed similar trends, except for the lateral fossa; higher scores on this axis showed also a greater relative development of the olecranon and a deeper trochlear notch (Fig. 6).

In the relative warp analysis (Fig. 7), RW1 tended to segregate males and females, and main features associated to high scores (mostly females) were a higher curvature of the bone and a notorious enlargement and displacement of the lateral fossa towards distal. On RW2, segregation was more marked to males, and the principal distortions affected the ulnar curvature and the shape and relative development of the olecranon. The individual landmark with the greatest variation was number 14 (base of the olecranon peak), which represented $28.1 \%$ of the variance.

As with the humerus, regression between Procrustes coordinates and the logarithm of the centroid size for the whole data set demonstrated that only a small amount of the variance $(6.8 \%)$ was explained by allometry $(\mathrm{p}=0.0009)$. 

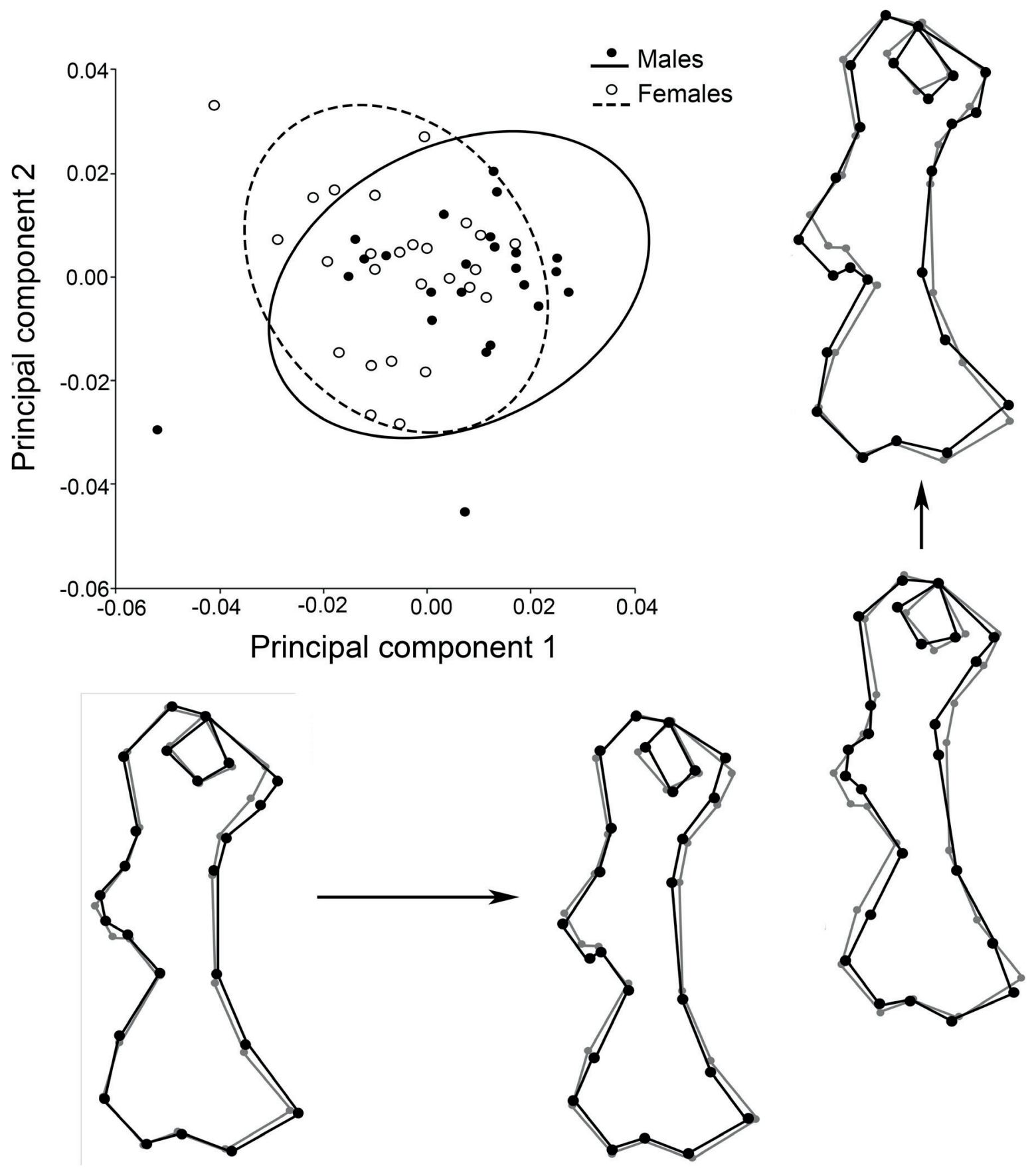

Fig. 3. Scatterplot for the humerus of Chaetophractus villosus (Desmarest, 1804), showing the distribution of the individuals in the plane formed by the two first principal components. The black outlines below the plot represent the shape variation associated to PC1, and those of the right show the changes associated to PC2 with respect to the consensus of the species (grey outlines).

\section{DISCUSSION}

Fossoriality plays an important role in the ecology of most armadillos, because underground tunnels allow them to cope with the adverse effects that exert the environment over their incomplete thermoregulatory capacities (see McNAB, 1980, 1985; CaSAnave \& Affanni, 1994). These mammals use the scratch digging strategy, which is considered to be the ancestral mammalian digging pattern (LESSA et al., 2008; Hopkins \& Davis, 2009; Morgan \& Verzi, 2011). Even though this mode of burrowing involves lesser evolutionary specializations for fossoriality than other digging patterns (HoPKINS \& DAVIS, 2009), all scratch diggers are characterised by several common features of their forelimb that result in the application of great out-forces (HILDEBRAND, 1985), favouring strength of extension over speed (MAYNARD SMITH 


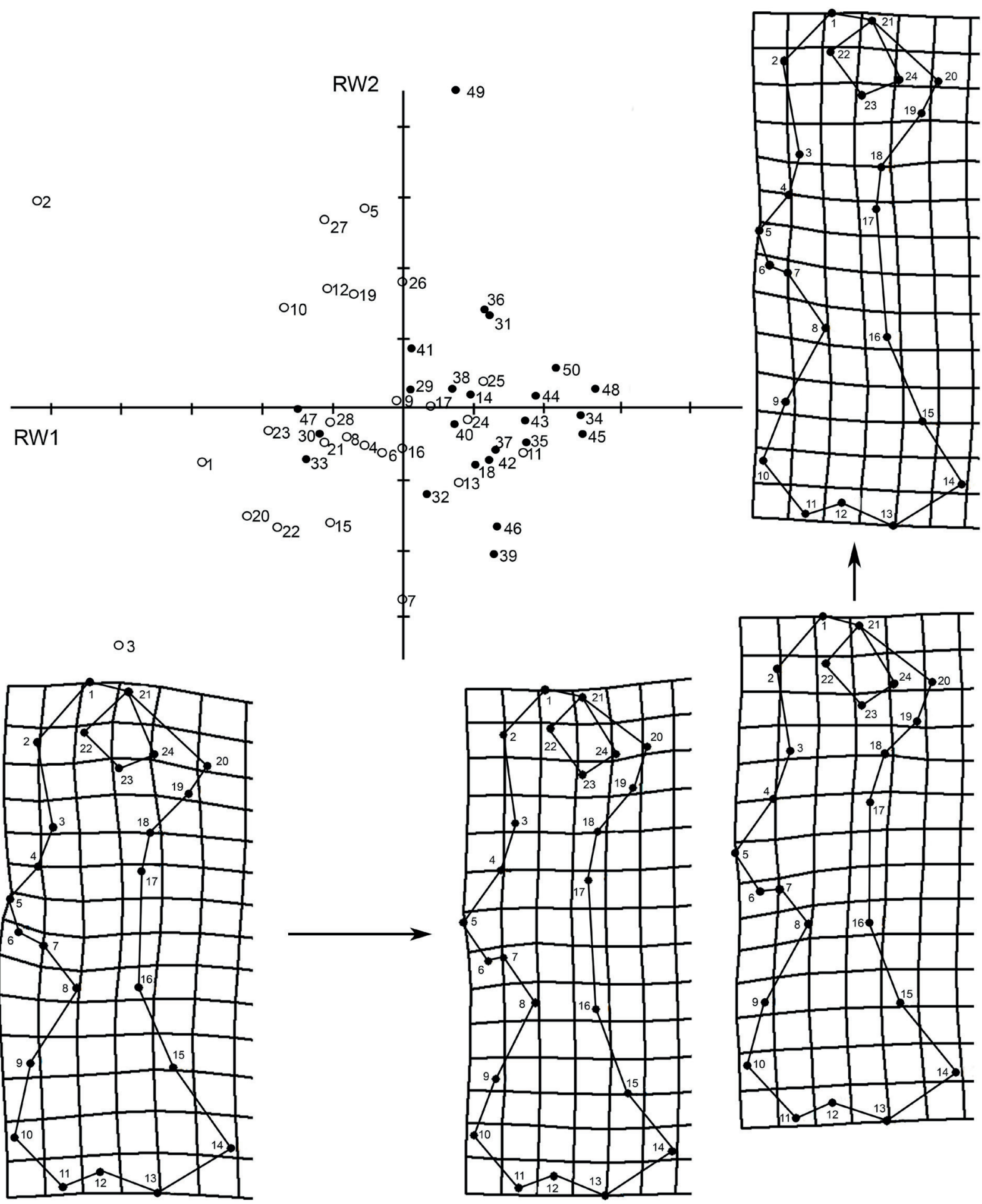

Fig. 4. Humerus. Distribution of males (black dots) and females (white dots) of Chaetophractus villosus (Desmarest, 1804) in the plane determined by the first two relative warps (RW1 and RW2). Numbers indicate specimens. Deformation grids below the graph show shape changes linked to negative (left) and positive (right) scores in RW1. Grids on the right show deformations linked to negative (below) and positive (above) scores in RW2.

\& Savage, 1956; Kley \& Kearney, 2007; Polly, 2007). The increasing of out-forces can be attained by enhancing the in-forces or the related in-levers, or by decreasing the out-levers (HILDEBRAND, 1985).

The fossorial adaptations in the appendicular skeleton of dasypodids are relatively well known from a variety of studies (e.g. VizCAínO et al., 1999; VizCAínO \& Milne, 2002; MiLne et al., 2009; GALLIARI, 2014). However, all of them address the issue at the specific level, without performing a distinction between sexes. According to RaLLS (1977), the Edentata (at present Xenarthra) are a group with a small to moderate degree of sexual dimorphism, with males generally 

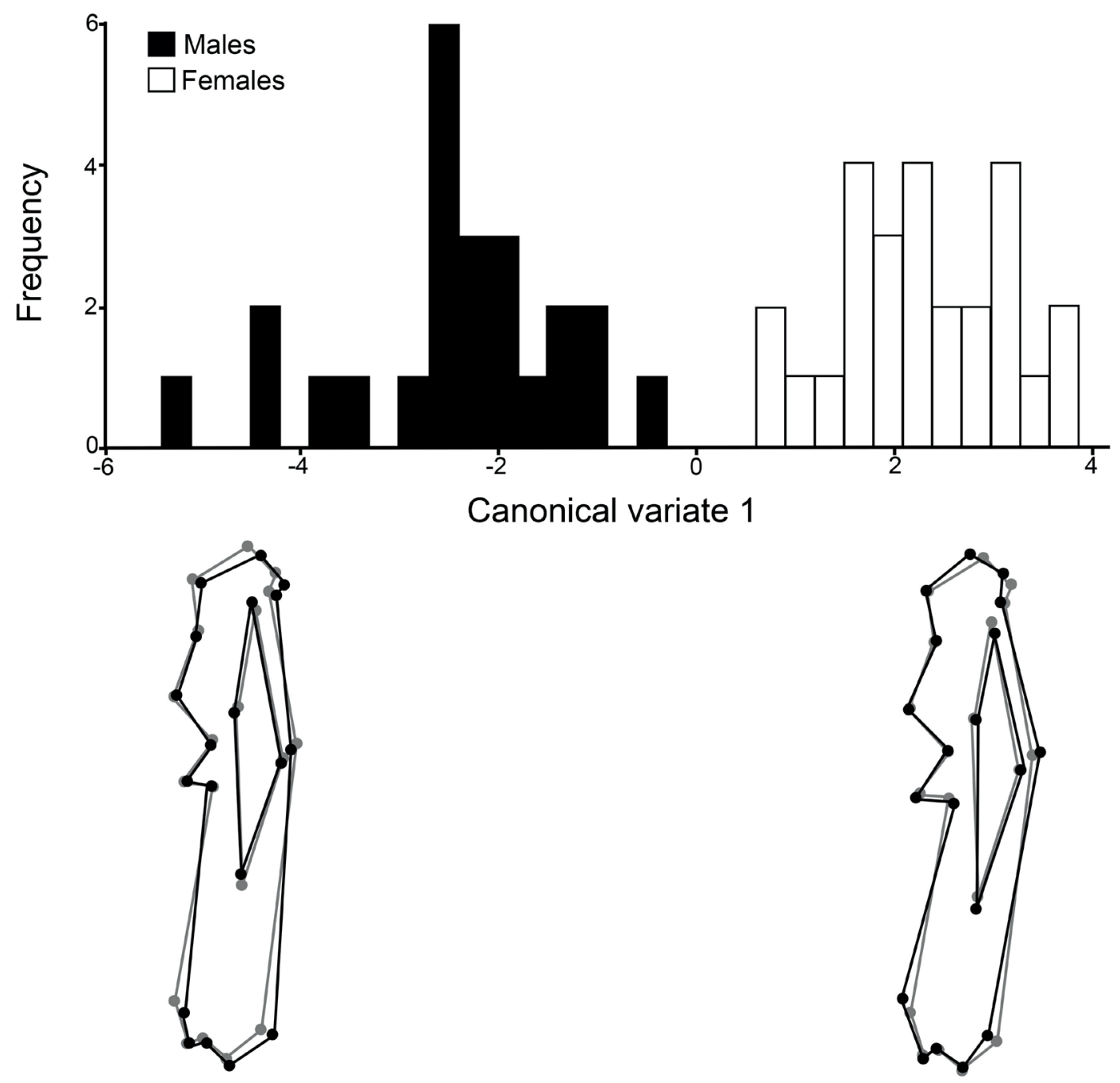

Fig. 5. Canonical analysis for the ulna of males and females of Chaetophractus villosus (Desmarest, 1804). The bone outlines below the graph represent extreme individuals (black dots and lines) with respect to the consensus of the species (grey dots and lines) along the axis.

larger than females. Results of SQUARCiA et al. (1993, 1994, 1999, 2009) demonstrated for C. villosus a clear-cut sexual size dimorphism in the skull and mandible but, contrarily to the vision of RALLS (1977), females were larger than males for both structures. This does not seem to be the general trend for the whole skeletal system of the species, since the morphometric analysis in this work showed the absence of size differences in appendicular elements between sexes. Instead, a slight shape-based sexual dimorphism in the humerus and ulna was noticed, with higher development in the females of structures that have been traditionally associated with the ability to dig.

Scapula. The absence of sexual dimorphism in the scapula of armadillos has been demonstrated for Euphractus sexcinctus by MonTeIRo (2000). In mammals in general, notwithstanding the scarcity of studies on that topic, the lack of sex differences has been reported for example in some species of cricetid rodents (VENTURA, 1992; TAYLOR
\& Siegel, 1995) and porpoises (Galatius, 2005). Based on Monteiro \& ABE (1999), the shape of the xenarthran scapula is under phylogenetic and functional influence. The coracoid component (small-scale region) is phylogenetically conservative, whereas the scapular blade (large-scale region, where the majority of muscles originate and insert) is mostly influenced by functional demands. Our analysis did not detect differences in scapula of males and females of $C$. villosus, owing probably to the small sample size which was not enough to offset the large morphological variability of the bone. However, if taking into account that differences in the humerus and ulna of both sexes were concentrated in the insertion sites of the major muscles involved in digging activities (see below), we do not discard the existence of shape dimorphism based on different functional demands (related to a differential muscular development) in the scapular blade of both sexes. A similar situation could occur in the glenoid, a common site of intra- and interspecific variation in the 

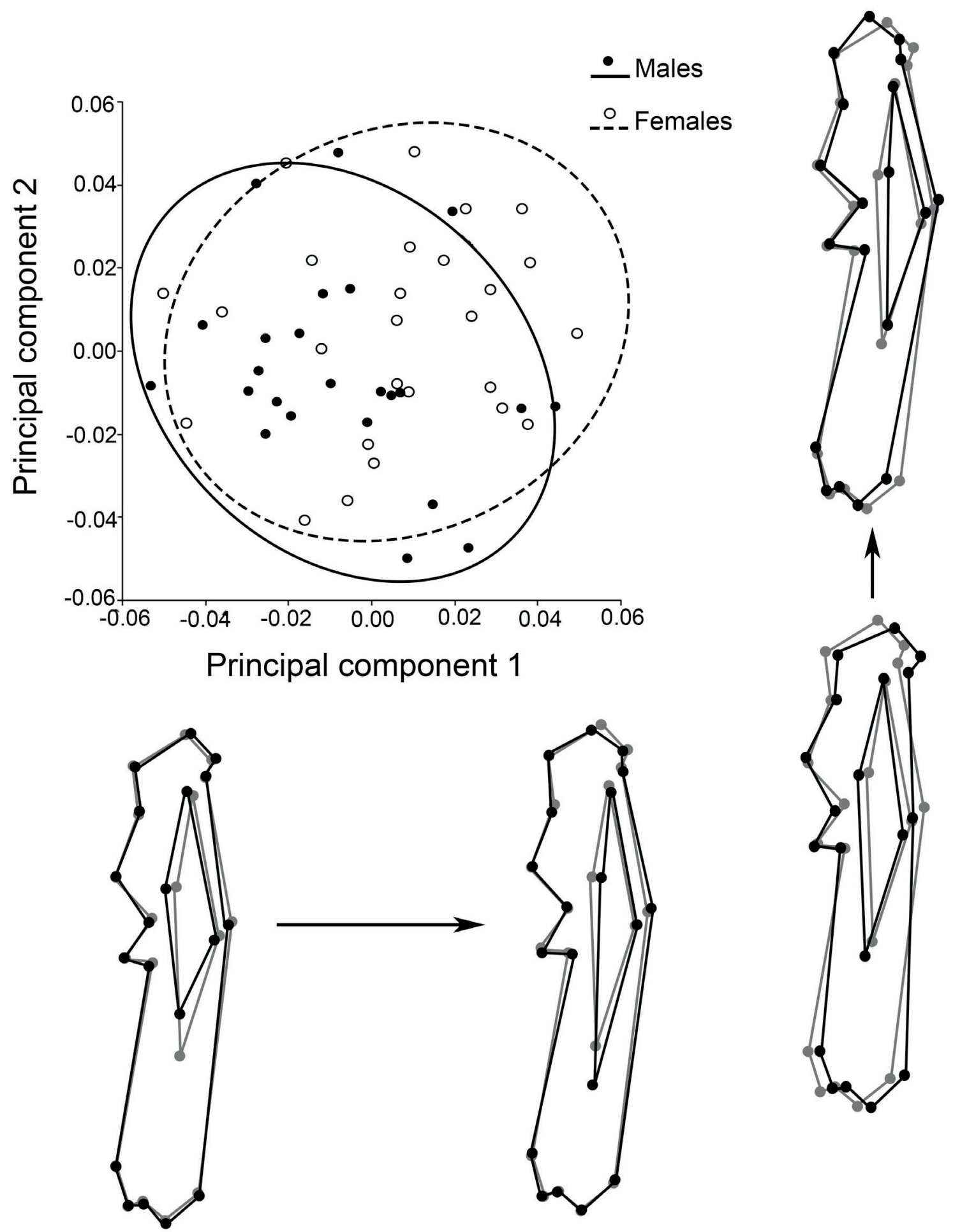

Fig. 6. Scatterplot for the ulna of Chaetophractus villosus (Desmarest, 1804), showing the distribution of the individuals in the plane formed by the two first principal components. The black outlines below the plot represent the shape variation associated to PC1, and those of the right show the changes associated to $\mathrm{PC} 2$ with respect to the consensus of the species (grey outlines).

mammalian scapula (RoBERTS, 1974; TAYLOR, 1974; SALTON \& SARGIS, 2008; Young, 2008; VANDERBECK et al., 2009; PREUSChOFT et al., 2010) but detecting such differences, if any, would require sampling at a different plane to that considered in this study.
Humerus and ulna. The outstanding shape differences in the humerus and ulna of males and females of $C$. villosus concentrated at the attachment sites for the main muscles involved in digging, and only a few amount of such variability was related with allometry (less than $7 \%$ 

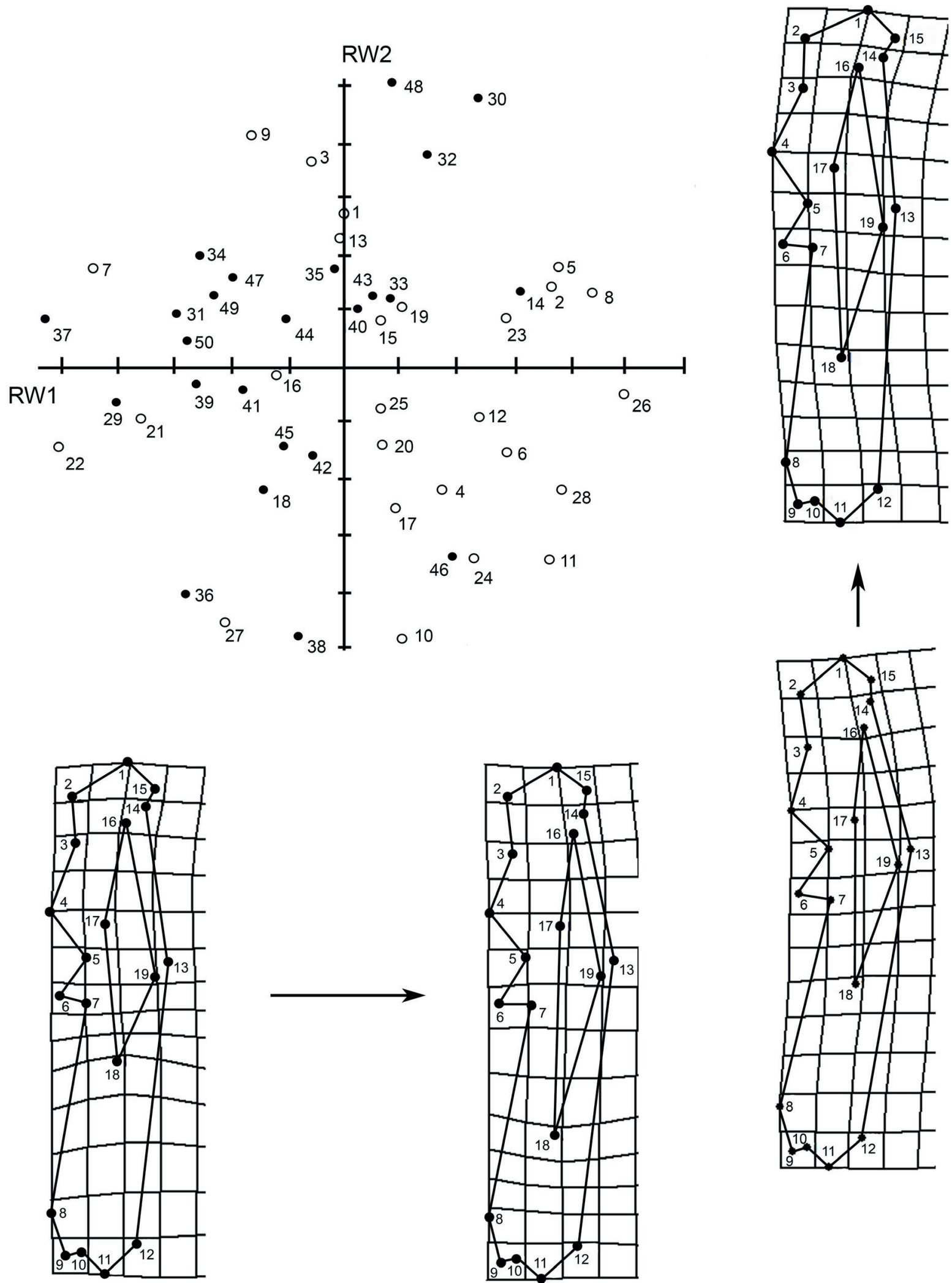

Fig. 7. Ulna. Distribution of males (black dots) and females (white dots) of Chaetophractus villosus (Desmarest, 1804) in the plane determined by the first two relative warps (RW1 and RW2). Numbers indicate specimens. Deformation grids below the graph show shape changes linked to negative (left) and positive (right) scores in RW1. Grids on the right show deformations linked to negative (below) and positive (above) scores in RW2. 
for both bones). Humerus in females characterised by a somewhat more robust morphology with several features that would increase the in-forces and the related in-levers. The deltoid tuberosity is more sturdy and salient, indicating a well-developed attachment sites for the acromiodeltoideus, clavodeltoideus and spinodeltoideus (the three components of the deltoideus). The arrangement at the female shoulder seem to impart structural strength to the use of the limb in a powerful digging stroke while keeping the required stabilisation, which could be attained by combining the great development of the deltoideus, a spherical humeral head and a medially enlarged lesser tubercle. The shape of the humeral head has been shown to play an important role in the mobility of the shoulder in mammals (Rose, 1989; MuIzon \& Argot, 2003; SAlton \& SARgis, 2008; Preuschoft et al., 2010), although its relationship with the mode of locomotion is not always clear (see CANDEla \& PICASSO, 2008). In marsupials, a hemispherical humeral head was related to an increased range of movements in a multidimensional space (typical of climbing or arboreal animals), whereas a transversely compressed head was associated to more sagittal movements and thus to more terrestrial habits (MuIzon \& Argot, 2003). The lateral protrusion of the tubercles may increase the lever arm of the musculotendinous "rotator cuff" (supraspinatus, infraspinatus, and teres minor: insertion at the greater tubercle; subscapularis: insertion at the lesser tubercle), enhancing also the stabilisation of the glenohumeral joint against compressional forces (RoBERTs, 1974; MUIZON $\&$ ARGOT, 2003). In the females of C. villosus it seems that the subscapularis has a preponderant role in stabilising the articulation judging by the marked prominence of the lesser tubercle. This configuration could provide also increased leverage for the latissimus dorsi and teres major muscles by deepening the bicipital groove, although this was not evident in the plane sampled by the landmarks.

MiLne et al. (2009) performed a geometric morphometric study of the humerus of several species of extant and fossil armadillos, covering a diverse range of locomotor behaviours. They observed that adaptations to digging ability were mostly related to a secure elbow joint and powerful muscles that were involved in the control of the forearm and hand. In our case, the distal end of the humerus of females showed characteristics that seemed to bestow a higher stability at the articulation than that of the males. The stronger and enlarged medial epicondyle and the well-developed supracondylar crest emphasises the torque of the carpal and digital flexors, when the digits must exert maximum force to achieve the cleavage of the substrate. The deeper trochlear notch of the ulna suggests also a higher stability of the elbow joint, not only during digging, but also in all stances. The great stability that confers a deep trochlear notch to fossorial animals was mentioned by EDWARDS (1937) for the mole Scalops aquaticus. Generally, mammals with deep trochlear notches are characterised also by humeri with proximally extended trochleae and wide olecranon fossae, as well as long olecranon processes (MUIZON \& ARGOT, 2003; WALKER, 2003); although the latter was evident in the females of C. villosus, we did not find differences between sexes at the level of the trochlea nor did examine the olecranon fossa to seek for differences in its shape or size. Notwithstanding, an enlarged fossa probably exists in accordance with the higher development of the olecranon.

The larger olecranon process of the females represented a clear mechanical advantage for the triceps; this muscle, that constitutes the main elbow extensor, reaches a great development in armadillos (based on the description of Dasypus novemcinctus by MiLes, 1941). The benefits of the females in terms of extension and retraction of the forearm were also evident from the remaining morphological features of the ulna. On the one hand, the curvature of the bone could increase the traction forces that operate during flexion (mediated by the biceps and brachialis) and extension movements. On the other, the traction force exerted by the triceps could be greatly emphasised by the agonistic anconeus, whose insertion (or at least in part) occurs at the distally displaced lateral fossa. Muscular insertions far from the articular joint they move result in long lever-arms and, consequently, in low-gear ratios (sensu HiLDEBRAND, 1988), increasing the force applied against the substrate.

The results obtained in this study are reinforced by previous observations relative to the brachial index in males and females of $C$. villosus. This index is defined as the functional length of the ulna (difference between ulnar length and olecranon length) divided by the humerus length $(\mathrm{BI}=[\mathrm{UL}-\mathrm{OL}] / \mathrm{HL})$, i.e. represents the out-lever/in-lever ratio. For mammals in general, higher values of BI are linked to less-specialised digger forms because they are indicative of relatively longer antebrachia, which reduces the power of movement but increases its rapidity (SARGIS, 2002; VIZCAÍNO \& Milne, 2002; Toledo et al., 2012; Rose et al., 2014). In C. villosus, we have registered higher BI in males than in females (unpublished) suggesting that, within the generalised fossorial morphotype of the species, males could have a more cursorial behaviour, with higher prevalence of fast movements over females.

Studies performed by AвBA et al. (2005) in Buenos Aires province (Central Argentina), have demonstrated that $C$. villosus constructs simple and complex burrows; the first type is built by animals searching for food or as temporary shelters, whereas the complex ones, longer, are constructed as home burrows. Similar results were reported by POLJAK et al. (2007) in Isla Grande (Tierra del Fuego, Southern Argentina). However, nothing is known about the participation of the sexes in the construction of these tunnels. The present work constitutes the first record of sexual dimorphism in some components of the appendicular skeleton of the species, with morphological traits that suggest a fossorial advantage in females. Further ecological studies are needed to investigate if this advantage mirrors a more active role in burrow construction.

Acknowledgements. The authors thank to Lic. Mariela Lodovichi for her assistance in the data analysis. The financial support by the Secretaría General de Ciencia y Tecnología, Universidad Nacional del Sur (Project PGI 24/B198) is also acknowledged. 


\section{REFERENCES}

Abba, A. M.; Udrizar Sauthier, D. E. \& Vizcaíno, S. F. 2005. Distribution and use of burrows and tunnels of Chaetophractus villosus (Mammalia, Xenarthra) in the eastern Argentinean pampas. Acta Theriologica 50(1):115-124.

BuRNe, R. H. 1901. A contribution to the myology and visceral anatomy of Chlamyphorus truncatus. Journal of Zoology 1:104-121.

Candela, A. M. \& Picasso, M. B. J. 2008. Functional anatomy of the limbs of Erethizontidae (Rodentia, Caviomorpha): Indicators of locomotor behavior in Miocene Porcupines. Journal of Morphology 269(5):552593.

Casanave, E. \& Affanni, J. 1994. Body temperature of the armadillo Chaetophractus villosus (Mammalia, Dasypodidae). Archives Internationales de Physiologie, de Biochimie et de Biophysique 102(5):243-246.

EDWARDS, L. F. 1937. Morphology of the forelimb of the mole (Scalops aquaticus, L.) in relation to its fossorial habits. Ohio Journal of Science 37(1):20-41.

Galatius, A. 2005. Sexually dimorphic proportions of the harbour porpoise (Phocoena phocoena) skeleton. Journal of Anatomy 206(2):141-154.

Galliari, F. C. 2014. El tipo scratch-digger en dos armadillos (Dasypodidae, Xenarthra): ontogenia esqueletaria de las manos y variaciones de dígitos. Revista del Museo de La Plata 24(183):1-14.

Galton, J. C. 1868. The muscles of the fore and hind limbs in Dasypus sexcinctus. Transactions of the Linnean Society of London 26(3):523566.

Gardner, A. L. 2005. Order Cingulata. In: Wilson, D. E. \& Reeder D. M. eds. Mammal Species of the World. 3ed. Baltimore, Johns Hopkins University Press, p. 94-99.

Hildebrand, M. 1985. Digging of quadrupeds. In: Hildebrand, M.; Bramble, D. M.; Liem, K. F. \& WaKe, D. B. eds. Functional Vertebrate Morphology. Cambridge, Belknap Press, p. 89-109.

Hildebrand, M. 1988. Analysis of vertebrate structure. New York, John Wiley \& Sons. 701p.

Hopkins, S. B. \& DAvis, E. B. 2009. Quantitative morphological proxies for fossoriality in small mammals. Journal of Mammalogy 90(6):14491460 .

InFoStAT. 2006. Grupo InfoStat, FCA, Universidad Nacional de Córdoba, Argentina.

Kley, N. J. \& Kearney, M. 2007. Adaptations for digging and burrowing. In: HALL, B. K. ed. Fins into Limbs: Evolution, Development, and Transformation. Chicago, University of Chicago Press, p. 284-309.

KLINGEnBerG, C. P. 2011. MorphoJ: an integrated software package for geometric morphometrics. Molecular Ecology 11(2):353-357.

Lessa, E. P.; Vassallo, A. I.; Verzi, D. H. \& Mora, M. S. 2008. Evolution of morphological adaptations for digging in living and extinct ctenomyid and octodontid rodents. Biological Journal of the Linnean Society 95(2):267-283

MaYnard Smith, J. \& SaVAGe, R. J. G. 1956. Some locomotory adaptations in mammals. Journal of the Linnean Society, Zoology 42(288):603-622.

McDonough, C. \& Loughry, W. 2008. Behavioral ecology of armadillos. In: Vizcaíno, S. \& Loughry, W. eds. The Biology of the Xenarthra. Gainesville, University of Florida Press, p. 281-293.

MCNAB, B. K. 1980. Energetics and the limits to a temperate distribution in armadillos. Journal of Mammalogy 61(4):606-627.

MCNAB, B. K. 1985. Energetics, population biology, and distribution of Xenarthrans, living and extinct. In: Montgomery, G. G. ed. The evolution and ecology of armadillos, sloths, and vermilinguas. Washington DC, Smithsonian Institution Press, p. 219-232.

Miles, S. S. 1941. The shoulder anatomy of the armadillo. Journal of Mammalogy 22(2):157-169.

Milne, N.; Vizcaíno, S. F. \& Fernicola, J. C. 2009. A 3D geometric morphometric analysis of digging ability in the extant and fossil cingulate humerus. Journal of Zoology 278(1):48-56.

Monteiro, L. 2000. Geometric morphometrics and the development of complex structures: ontogenetic changes in scapular shape of dasypodid armadillos. Hystrix 11(1):91-98.

Monteiro, L. R. \& ABe, A. S. 1999. Functional and historical determinants of shape in the scapula of Xenarthran mammals: evolution of a complex morphological structure. Journal of Morphology 241(3):251-263.
Morgan, C. C. \& Verzi, D. H. 2011. Carpal-metacarpal specializations for burrowing in South American octodontoid rodents. Journal of Anatomy 219(2): 167-175.

Muizon, C. DE \& Argot, C. 2003. Comparative anatomy of the Tiupampa didelphimorphs; An approach to locomotory habits of early marsupials. In: Jones, M.; Dickman, C. \& Archer, M. eds. Predators with Pouches: The Biology of Carnivorous Marsupials. Collingwood, CSIRO Publishing, p. 43-62.

Poljak, S.; Escobar, J.; Deferrari, G. \& Lizarralde, M. 2007. Un nuevo mamífero introducido en la Tierra del Fuego: el "peludo" Chaetophractus villosus (Mammalia, Dasypodidae) en Isla Grande. Revista Chilena de Historia Natural 80(3):285-294.

Polly, P. D. 2007. Limbs in mammalian evolution. In: Hall, B. K. ed. Fins into Limbs: Evolution, Development, and Transformation. Chicago, University of Chicago Press, p. 245-268.

Preuschoft, H.; Hohn, B.; Scherf, H.; Schmidt, M.; Krause, C. \& Witzel, U. 2010. Functional Analysis of the Primate Shoulder. International Journal of Primatology 31(2):301-320.

RALLS, K. 1977. Sexual dimorphism in mammals: avian models and unanswered questions. The American Naturalist 111(981):917-938.

RedFord, K. H. \& EisenberG, J. F. 1992. Order Xenarthra (Edentata). In: Redford, K. H. \& Eisenberg, J. F. eds. Mammals of the Neotropics. Chicago, University of Chicago Press, v. 2, p. 46-68.

RoBERTS, D. 1974. Structure and function of the primate scapula. In: JENKINS, F. E. JR. ed. Primate locomotion. New York, Academic Press, p. 171-200.

Rohlf, F. J. 2010a. TPSDig2, version 2.16. New York, Stony Brook. Available at $<$ http://life.bio.sunysb.edu/morph/ $>$. Accessed on 21 November 2016.

Rohlf, F. J. 2010b. TPSRelw, version 1.49. New York, Stony Brook. Available at $<$ http://life.bio.sunysb.edu/morph/ $>$. Accessed on 21 November 2016.

Rose, M. D. 1989. New postcranial specimens of catarrhines from the Middle Miocene Chinji Formation, Pakistan: descriptions and a discussion of proximal humeral functional morphology in anthropoids. Journal of Human Evolution 18(2):131-162.

Rose, J.; Moore, A.; Russell, A. \& Butcher, M. 2014. Functional osteology of the forelimb digging apparatus of badgers. Journal of Mammalogy 95(3):543-558

Salton, J. A. \& SARgis, E. J. 2008. Evolutionary morphology of the Tenrecoidea (Mammalia) forelimb skeleton. In: SARGIS, E. J. \& Dagosto, M. eds. Mammalian Evolutionary Morphology: A Tribute to Frederick S. Szalay. New York, Springer, p. 51-71.

SARGIS, E. J. 2002. Functional morphology of the forelimb of Tupaiids (Mammalia, Scandentia) and its phylogenetic implications. Journal of Morphology 253(1):10-42.

Squarcia, S. M.; Casanave, E. B. \& Cirone, G. R. 1993. Morfología craneana de Chaetophractus villosus (Mammalia, Dasypodidae). Iheringia, Série Zoologia (75):55-56.

Squarcia, S. M.; Casanave, E. B. \& Cirone, G. R. 1994. Morfometría craneana de Chaetophractus villosus (Mammalia, Dasypodidae). Anales del Museo de Historia Natural de Valparaíso 22:103-106.

Souarcia, S. M.; Casanave, E. B. \& Cirone, G. R. 1999. Sexual dimorphism in Chaetophractus villosus (Mammalia, Dasypodidae) based on craniometrical characters. Anales del Museo de Historia Natural de Valparaíso 24:91-94.

Squarcia, S. M.; Sidorkewicj, N. S.; Camina, R. \& Casanave, E. B. 2009. Sexual dimorphism in the mandible of the armadillo Chaetophractus villosus (Desmarest, 1804) (Dasypodidae) from northern Patagonia, Argentina. Brazilian Journal of Biology 69(2):347-352.

TAYLOR, M. E. 1974. The functional anatomy of the forelimb of some African Viverridae (Carnivora). Journal of Morphology 143(3):307-336.

TAYLOR, A. B. \& Siegel, M. I. 1995. Modeling differences in biological shape in two species of Peromyscus. Journal of Mammalogy 76(3):828-842.

Toledo, N.; Bargo, M. S.; Cassini, G. H. \& Vizcaíno, S. F. 2012. The forelimb of Early Miocene sloths (Mammalia, Xenarthra, Folivora): Morphometrics and functional implications for substrate preferences. Journal of Mammalian Evolution 19(3):185-198.

Vanderbeck, J. L.; Fenlin, J. M. Jr.; Getz, C. L. \& DePalma, A. F. 2009. Congenital anomalies and variational anatomy of the shoulder. In: Rockwood, C. A. JR. \& Matsen, F. A. eds. The Shoulder. 4ed. Philadelphia, Saunders, v. 1, p. 101-143. 
Ventura, J. 1992. Morphometric data on the scapula and limb long bones of Arvicola terrestris (Linnaeus, 1758) (Rodentia, Arvicolidae). Revue Suisse de Zoologie 99(3):629-636.

Vizcaíno, S. F.; Fernicola, J. C. \& Bargo, M. S. 2012. Paleobiology of Santacrucian glyptodonts and armadillos (Xenarthra, Cingulata). In: Vizcaíno, S. F.; FAY, R. F. \& Bargo, M. S. eds. Early Miocene Paleobiology in Patagonia: High-Latitude Paleocommunities of the Santa Cruz Formation. Cambridge, Cambridge University Press, p. 194-215.

VizcaínO, S. F.; FARiña, R. A. \& MazzetTA, G. 1999. Ulnar dimensions and fossoriality in armadillos and other South American mammals. Acta Theriologica 44(3):309-320.

Vizcaíno, S. F. \& Milne, N. 2002. Structure and function in armadillo limbs (Mammalia, Xenarthra: Dasypodidae). Journal of Zoology 257(1):117-127.

Vizcaíno, S. F.; Milne, N. \& BARGo, M. S. 2003. Limb reconstruction of Eutatus seguini (Mammalia: Xenarthra: Dasypodidae). Paleobiological implications. Ameghiniana 40(1):89-101.
WALKer, A. 2003. Locomotor adaptations in past and present prosimian primates. In: Jones, M.; Dickman, C. \& Archer, M. eds. Predators with Pouches: The Biology of Carnivorous Marsupials. Collingwood, CSIRO Publishing, p. 349-381.

Wetzel, R. M.; Gardner, A. L.; Redford, K. H. \& EisenberG, J. H. 2008. Order Cingulata. In: GARDNer, A. L. ed. Mammals of South America: Marsupials, Xenarthrans, Shrews, and Bats. Chicago, University of Chicago Press, p. 128-156.

Windle, B. C. A. \& Parsons, F. G. 1899. On the myology of the Edentata. Part I. Muscles of the head, neck and fore limb. Proceedings of the Zoological Society of London: 314-339.

Young, N. M. 2008. A comparison of the ontogeny of shape variation in the anthropoid scapula: Functional and phylogenetic signal. American Journal of Physical Anthropology 136(3):247-264. 